International Journal of Instruction e-ISSN: 1308-1470 • www.e-iji.net
July $2017 \bullet$ Vol.10, No.3

p-ISSN: 1694-609X

pp. $179-194$

Received: 08/02/2017

Revision: 28/04/2017

Accepted: 30/04/2017

\title{
High School Graduates' Readiness for Tertiary Education in Saudi Arabia
}

\author{
Heba Bakr Khoshaim
}

Asst. Prof., Prince Sultan University, Kingdom of Saudi Arabia, hkhoshaim@psu.edu.sa

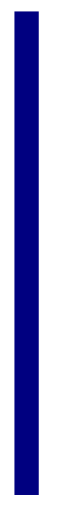

There has been a huge improvement in the education system in Saudi Arabia quantitatively and qualitatively. Nevertheless, many researchers indicated that high school graduates are not ready for higher education. Especially when considering mathematical compensations, high-demanded skills for tertiary academic programs, Saudi students have been found deficient. Lots of them fail - and hence, quit-from the very first year. There have been several approaches that addressed the challenge of transition from secondary education to higher education. Some of these attempts addressed school curricula. Others focused on improving students' competencies during their first year at university. This paper elaborates on KSA recent movements to address the challenges that students face when moving to higher education institutions. It then, explains the performance of students at a private university in Saudi Arabia during the transition period and particularly when they complete the mandatory preparatory year program.

Keywords: higher education, mathematical competencies, preparatory year program, transition to tertiary education

\section{INTRODUCTION}

The history of higher education in the Kingdom of Saudi Arabia (KSA) is about 70 years old. Back in 1949, the College of Islamic Low was the only institution beyond high school. The first university in KSA and in the whole Gulf region, however, is King Saud University (KSU), which was established in 1957 in the capital city Riyadh. Few years later, King Fahad University of Petroleum and Minerals was established in 1963 followed by King Abdulaziz University in 1967 and Umm Al-Qura University in 1969. By 2003, around half a million Saudi high school graduates had the opportunity to complete their higher education at eight public and seven private universities. Although, this achievement in only 50 years is considered remarkable, what is more admirable is that in 2016 - only one decade later-there were 75 public and private colleges and universities in KSA (Al-Amri, 2011), with over one million and a half enrolled students. In addition, over 150,000 students are studying abroad with governmental financial support (Ministry of Education, n.a.), which makes the kingdom number four in the world when it comes to the number of abroad scholarships (Al-Amri, 2011). Such 
numbers speak of the commitments to higher education and exemplify the efforts to achieve such improvement.

\section{The Problem}

Despite the outstanding improvement in the quantity of higher education institutions in the kingdom, educational stakeholders have soon realized that not all those who join higher education institutions succeed! Many high school graduates are not ready for college (AlMoshari AlSaud, 2012; Alnatheer, 2009; Hastings, 2012). When we consider mathematical skills - a high-demanded talent at most undergraduate programs - many students are found deficient (AlHarbi, 2012; Khoshaim \& Ali, 2015-a). Saudi media has consistently indicated that high school graduates lack practical and technical skills, which make it convincing that high school graduates cannot survive college-level mathematics courses (Khoshaim \& Ali, 2015-b).

\section{Consequences of the Problem}

Most university-level academic programs nowadays are mathematically-intensive. Actually, mathematical compensations are considered as a major factor behind students' success at universities, especially during their first year. This argument is supported by numerous research findings (Uyar \& Güngörmüş, 2011). Moreover, most higher education institutions take into account an applicant's mathematical skills before admission. Students' struggle during first year at college results in stress, demotivation, and even depression. Some students might have the ability to pick up the missing skills and get on track in their academic programs. In fact, Dimitrov and AlHarbi (2012) suggested in their analysis on a sample from a Saudi university that students' performance after three semesters is better that their performance in their first semester. For others, however, the struggle caused them to change their major or even quit education. Unfortunately, higher education institutions are held accountable of dropout rates (Lobo, 2012). In addition, dropout rates affect economic status of higher education institutions. Hence, KSA is committed to enhance and improve the quality of its educational system (Oxford Business Group, 2012). The goal of this paper is twofold: First, to discuss KSA recent approaches to address the challenges that Saudi students face when moving to higher education institutions. Second, the paper uses descriptive statistics to explain students' performance during the Preparatory Year Program (PYP), a mandatory program for students joining higher education in KSA.

\section{METHOD}

The goals of this paper were achieved in two stages.

Stage I: The first goal of the study was to elaborate on KSA recent approaches to address the challenges that Saudi students face when moving to higher education institutions. In this stage, the researcher collected data through previous reports, official documentaries and research findings to give an intensive review of the history of education at KSA; then, the researcher examined, analysed, and compared mathematical high school curricula 20 years ago and now to understand the processes that have been applied by different stakeholders to address the transition challenge. 
Stage II: The second goal of the study was to explain students' performance during the Preparatory Year Program (PYP). To achieve this goal the researcher looked at students' performance at a private university. First, all students who were admitted during the two consecutive years 2011-2012 and 2012-2013 were considered. Students were admitted to PYP only after satisfying the admission criteria at the university. Then, the researcher analyzed the data and excluded those who did not complete the PYP, those who withdraw from the university, and those who did not take mathematics during the PYP program. Finally, a random sampling techniques was used to select a total of 1200 students (746 female and 454 male) from this set of students who successfully completed the PYP.

This study used descriptive statistics to explain students' performance during PYP. Mean, standard deviations, minimum and maximum were computed for all students in the random sample. The main variable used is the Grade Point Average of students upon completing PYP. Moreover, the researcher examined the grade distribution and passing percentages of the mathematics courses offered in the PYP and specifically in these two years. Although the study focused only on one private university, the study considered all admitted students who satisfy the criteria of the research and then the sample selected was totally random. Moreover, the grade analysis techniques for mathematics courses included all sections for all mathematics courses in the PYP, which support the validity of the data.

\section{FINDINGS}

\section{STAGE I FINDINGS}

\section{Education in the Kingdom: Then and Now}

\section{Then}

Curricula and pedagogy

Since the beginning of schools in the kingdom, elementary through middle and secondary education is free of charge for all students. Curricula are unified across all schools and among all subjects under the supervision of the Ministry of Education. For example, all students in Grade 4 learn long division in their mathematics class. They explore linear equation with one variable in Grade 7 and geometry concepts in Grade 10, whereas they learn about trigonometric functions in Grade 11 and study basic calculus concepts in Grade 12. The contents of curricula as a whole are greatly appreciated by educators and meet international standards (Alshehri \& Ali, 2016). However, pedagogy, the presentation of knowledge, and the focus on certain subjects over others have been highly criticized (Khashoggi, 2014). It was believed that the curriculum was not implemented as intended (Excellence Research Center of Science and Mathematics Education, 2011). The educational culture in classrooms was what is known as spoon feeding education. "I will show you how to solve it and you follow"; this was the default approach. Saudi students at all levels wanted to be given knowledge instead of searching for it themselves. The classroom environment was teacher-centered (McMullen, 2014). Students lacked abstract, critical and analytical skills needed to 
address high level tasks (AlHarbi, 2012). They were more comfortable with procedural, few-steps, one-solution problems. They did not challenge themselves, but rather followed teacher's instruction and applied steps to reach the right answer, with very little thoughts about why it was the right answer. In fact, mathematics teachers avoided students' struggle when they address a cognitively demanding task; they provide immediate help with the very first sign of confusion, discomfort, or struggle. Teachers tried to maintain a comfortable, stress-free environment by giving away unnecessary hints (Alsaeed, 2012).

\section{The Language of Instruction}

The official language in KSA is Arabic. Hence, the instructional language at all secondary schools is Arabic, with an exception to few international private schools. This means that in mathematics classes, students learn mathematics terminologies, symbols, phrases and concepts only in Arabic. For example, consider a simple trigonometry task such as: Solve the following equation:

\section{$\cos x-1=0$}

This task was written in Grade 11 mathematics textbook as in Figure 1. English, on the other hand, was only introduced as a second language in schools in Grade 7. It was believed that many high school graduates were almost English illiterate. Moreover, many English language in-service teachers are considered insufficiently trained (AlSeghayer, 2014).

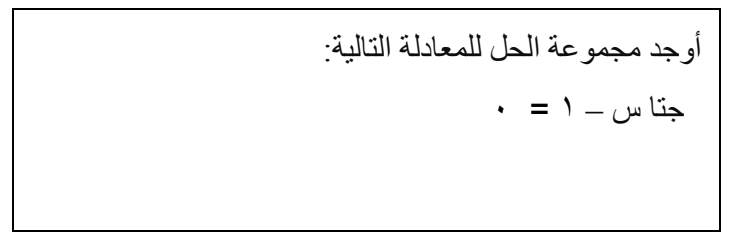

Figure 1

Trigonometry Task in Arabic

\section{Assessment and Readiness}

To assess students' readiness to graduate from secondary education, KSA used to apply a unified assessment system. A national high-stake, large-scale examinations were applied on all students ready to graduate from high school. The Ministry of Education was the sole responsible party of such examinations. To increase security and to ensure validity and fairness, the same assessment items were used for all subjects. In other words, students in Grade 12 had to take the same exam for every subject at exactly the same time and duration during a particular predetermined announced period. Upon successfully passing the exam for each subject, a high school diploma could be issued. To choose the assessment items, the Ministry of Education formed a national committee consisting of members from all provinces of the kingdom every year. Some high school teachers might be chosen as members of the committee. However, non-member teachers 
would see the exam items for the first time only when they were being distributed to students in the examination hall. Because Saudi Arabia applies unified curricula in all schools and for all subjects, this process was not only possible, it also supported the internal validity of the exams. Upon passing all exams, the student was granted a High School Diploma, which is used for admission to universities. The Grade Point Average (GPA) of high school was the only indicator of a student's proficiency, knowledge, or readiness.

\section{Now}

The population of the kingdom has grown from 21,392 million in 2000 to over 32 million in 2016. Around $50 \%$ of the citizens are below 25 . Hence, the expansion with regard to the number of schools or universities is somehow expected. The number of schools has grown from 3200 schools in 1970 to 23000 schools in 2000 and more than 50000 schools in 2016 (Ministry of Education, 2015). However, while quantity is on track, quality of graduates is of concern. Critiques have raised their concerns against the educational system and the quality of instructions. This is why the whole system has gone through a rapid transformation, which includes changing curricula at all levels.

Curricula and Pedagogy: Addressing the Challenge

Students in higher education are expected to be independent, pursue knowledge from several references, and address cognitively demanding tasks. However, unified curricula and textbooks in secondary education, straightforward tasks, and challenge-less learning atmosphere caused high school graduates to be resistant to higher education environment. This resulted in stress, low performance, and in many cases, quitting education after the first year of university. Students were not ready for the new environment's demands, and the way they were taught in schools was to blame to a great extent. Hence, KSA curricula have gone through a tremendous change in 2010. Mathematics textbooks now include world problems, cognitively demanding tasks and applied procedures. In fact, a recent study showed over $90 \%$ compatibility between mathematical contents taught in early secondary schools in KSA and the National Council of Teachers of Mathematics standards (Alshehri \& Ali, 2016). Moreover, pedagogy has been transformed. Teachers are asked to address students' problemsolving skills. They must encourage students to focus on analysis and critical thinking and address this in their assessment procedures (Alsaeed, 2012). Alsaeed indicated that mathematics teachers now encourage mathematical discourse, high-level tasks and multiple solutions. Mathematical classrooms today are full of collaboration, discussion, and group work. In other words, teachers are focusing on student-centered classroom instead of teacher-centered classroom (Asaeed, 2012). They encourage students' engagement, foster mathematical discourse, and promote high level thinking.

\section{The Language of Instruction: Addressing the Challenge}

Because English is considered the language of science and technology in most parts of the world, Saudi stakeholders "consider the value of English as highly practical; opportunistic and prestige" (Rahman \& Alhaisoni, 2013, p. 114). In fact, English now is number one official taught and spoken foreign language in the Kingdom (Al-Seghayer, 
2014) and the language of instruction in most academic programs in higher education institutions (McMullen, 2014), especially engineering and science programs. However, through all secondary education, the language of instruction is Arabic only. Hence, when high school graduates join universities, they face a problem to understand even mathematical terminologies and symbols. A student will fail to solve the task $\cos x-1=0$ just because he/she does not understand what $\operatorname{Cos}$ means and what is needed by the word solve. To address this language barrier, English is now introduced in schools as a second language from Grade 4 in all public schools. In addition, starting in 2010, a rapid change occurred in all secondary school curricula (Ministry of Education, n.d.). Mathematics textbooks introduced English mathematical terminology and symbols gradually along with their Arabic analogy in all school mathematics and science textbooks. The task itself and the language of instruction remain to be Arabic, though. For example: Figure 2 represents a Grade 10 geometry task in 2015 mathematics textbook. Students need to use the below diagram and the properties of congruent triangles to find the value of the angles $x, y$, and $z$. Two decades ago, this task two decades ago contained only pure Arabic terminology, alphabetic or numbers. Now, it contains symbols like $x$ and $y$ and capital letters such as A, B and C, although the instruction and heading of the task itself is in Arabic. Another example is shown in Figure 3, where the mathematics concept (Providing Triangle Congruent) is written in both languages. The goal is to get students to be familiar with the language and terminology to prepare them for a gradual movement to higher education.

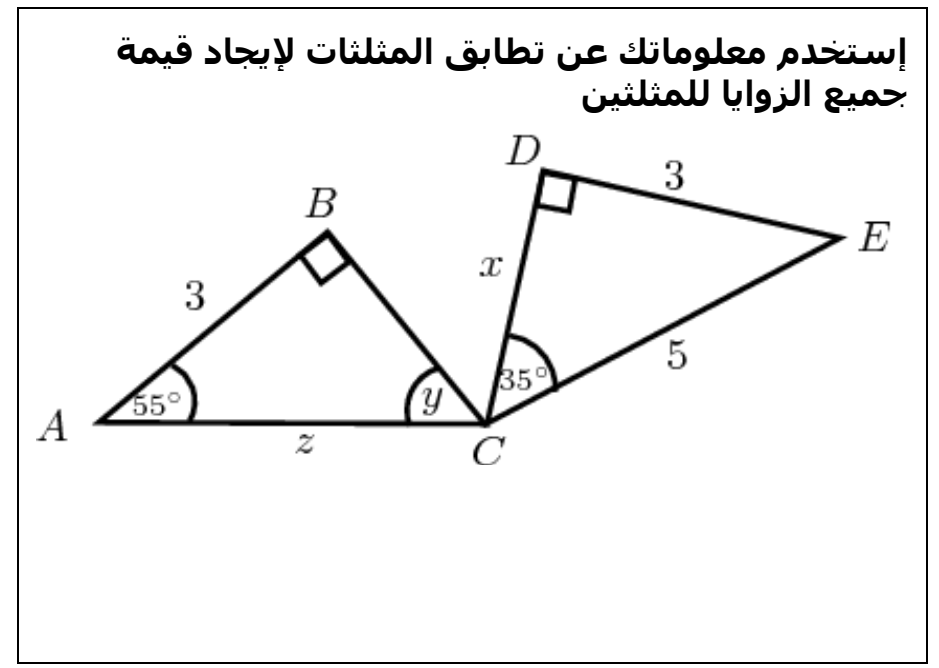

Figure 2

Geometry task with English numbers and symbols 


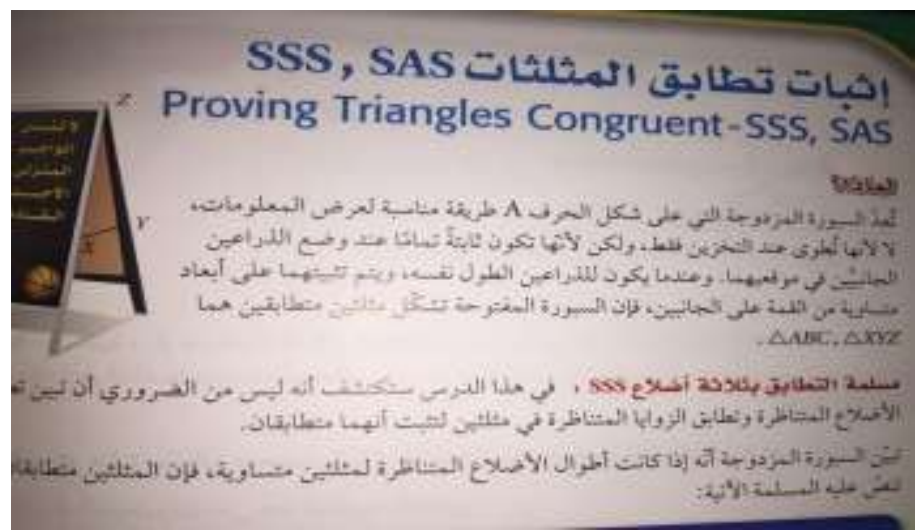

Figure 3

Heading in both languages Arabic and English

Assessment and Readiness: Addressing the Challenge

With the expansion of the number of schools and students, it was clear that the assessment process should be addressed. The unified assessment process was no longer easily maintained and administered. Moreover, stakeholders realized that graduating from high school does not mean joining a university. High school graduates might not be even interested in higher education, not to mention being ready for it. Research results supported the relationship between high school GPA (HSGPA) and students' achievements when they join higher education institutions (Alnahdi 2015; AlQataee \& AlHarbi, 2012; Atkinson \& Geiser, Zwick \& Sklar, 2005). However, other research studies supported the use of other admission criteria to higher education institutions, such as standardized examinations (Patterson, Mattern, \& Swerdzeskwi, 2012). For example: The General Certificate of Education Advanced Level (GCE-A Level) in the United Kingdom, The National Center test in Japan, the Baccalauréat in France, and Ögrenci Seçme Sinavi in Turkey are used to provide admission tickets to higher education institutions. Considering the practice in many parts of the world, Saudi educators and policy makers argued that high school diploma should not be the only admission criteria to universities. Hence, Saudi Arabia designed and implemented their own national standardized examinations.

Starting 2000, the National Center for Assessment in Higher Education (NCAHE) has been established. It is a nation-wide independent quality assurance and accreditation commission that is given the responsibility to detect student's potential abilities, academic skills, and readiness to higher education. Since 2000, admission to higher education institutions depends on three independent criteria: high school grade point average, the score of an aptitude test (General Aptitude Test) and the score of an achievement test (Standard Achievement Admission Test). Both the General Aptitude Test (GAT) and the Standard Achievement Admission Test (SAAT) are designed and offered by NCAHE. GAT has two parts: verbal and quantitative. GAT quantitative part measures students' ability to criticize and critique in general but not necessarily solve 
direct specific mathematical problems. However, SAAT will examine their skills with regard to knowledge learned in high school by addressing questions from the content itself. It is argued that the establishment of NCAHE helped in addressing some criticism facing by the educational system in the kingdom (Alnatheer, 2009) by improving the selection process at higher education institutions. Since the establishment of the NCAHE, several Saudi researchers examined the effectiveness of the new standardized assessment procedure. Research findings supported the validity of the SAAT and GAT tests as predictors of students' knowledge and skills (Alnahdi, 2015; Al-Owidha, 2013; AlQataee \& AlHarbi, 2012; Khoshaim \& Ali, 2015-a; Dimitrov \& AlHarbi, 2014). AlQataee and AlHarbi's study examined data from nine public universities, and concluded that $50 \%$ of the variance of students' performance is due to SAAT, $44 \%$ of the variance of students' performance is due to HSGPA and $41 \%$ of the variance of students' performance is due to GAT. In addition, Khoshaim \& Ali (2015-b) looked at data from a private university and suggested that $34 \%$ of the variance in mathematics performance of first year students is explained by GAT. Moreover, the GAT has been supported as a highly reliable assessment test with internal reliability reaching $90 \%$ (AlQataee, 2012). It was also suggested that GAT is a better predictor than HSGPA when it comes to students' graduation rather than their achievements in their first year (Alnahdi, 2015).

\section{THE PREPARATRY YEAR PROGRAM}

However, addressing secondary school curricula, transforming pedagogy and supporting the selection process to higher education institutions are not enough. Hence, KSA decided to provide additional support to students in their first year at higher education. Because, it was recognized that one of the very important tools to ease transition is to address students' readiness and to develop an independent learning habits (Bergsten, Jablonka, \& Ashjari, 2016), hence, the Preparatory Year Program (PYP) was established in all public and private higher education institutions. The PYP is one full academic year of preparatory education addressing mathematics, English language proficiency, computational skills, and personal development skills (Ministry of Education, n.d.). Students can join academic programs only upon successful completion of all PYP courses. The GPA of PYP is not counted once a student join an academic program.

Several strategies are used to support the PYP. In fact, many universities established a separate deanship that deals only with the program - the Preparatory Year Deanship (Alshumaimeri, 2013). In addition, in 2015, the first national conference of the preparatory year in Saudi universities was conducted at the University of Dammam with an aim to share, exchange and explore others experiences, feedback, and innovations. PYP deanships officials from around 25 higher education institutions in KSA participated in the conference. The theme of the conference focused on evaluating current experiences and thinking about the future (University of Dammam, n.d.)

\section{Goals of PYP}


One of the aims of PYP is to overcome the cultural spoon-feeding phenomena. PYP aims to transfer students from the comfortable guided teaching methods to a more independent seeking-for-knowledge approach. Students should be self-determinant and pursuant to knowledge. Students are expected to be active instead of passive learners. PYP address students' communication and personal skills. For example, at King Saud University-one of the leading high education institutions in KSA-teachers use elearning and Learning Management System, such as Blackboard, when teaching mathematics PYP courses to support the process of interaction and communication between teachers and students (Al-Jeraiwi, 2015). PYP teachers train students to deal with their new environment and meet the new expectations. They aim to teach students to critic, criticize and analyse instead of memorize. For example, one of the workshops provided in the First National Conference of Preparatory Year in Saudi Universities focused on providing "pedagogical tools" to the audience to help them teach critical thinking in their PYP classrooms (University of Dammam, n.d.).

In addition, PYP strives to strengthen students' English proficiency. The largest component of all PYP programs is the English proficiency courses. At KSU for example, PYP students should complete 8 credit hours of English courses per academic semester for two semesters (King Saud university, n.d.) This is designed as twenty contact hours per week for 15 weeks. There is a demand to hire native speakers to teach English in PYP in Saudi Arabian universities. Doing so empowers the process of learning and help students improve their language level faster as they engage not only with the knowledge but also with the culture (Alshumaimeri, 2013). Moreover, all PYP programs contain mathematics courses. PYP mathematics courses are taught in English (for science and medical colleges and schools). The aim is to ensure that students have the basic essential mathematical skills and that they know these skills in English. It is important to mention here that mathematics PYP courses might differ per college; students aiming to join engineering and science colleges will be introduced to more demanding mathematics courses than those perusing administration or humanities. For example, students joining Engineering at KSU should complete calculus I; whereas those aiming for humanities should only complete algebra and basic statistics courses.

\section{Evaluating the PYP}

PYP is deemed valuable not only by policy makers and educators but also by all stakeholders including students themselves (Alghamdi, 2015) and their families (McMullen, 2014). Recent studies have showed that PYP has been achieving its goals, at least partially. For example, Alshumaimeri (2013) suggested that the level of students' motivation increased upon completion of PYP. Hence, this suggests that students are motivationally ready to join their academic programs. In addition, students themselves perceived that the program is effective (Alshumaimeri \& Alghamdi, 2009). Moreover, Saudi newspapers have discussed stakeholders' point of views about the PYP and have reported that $24 \%$ believe that PYP improves students' skills in English and mathematics; whereas $21 \%$ believe that PYP helps in closing the gap between secondary education and higher education (Alenaizy, 2015). It is also important here to mention that Saudi universities are consistently trying to improve the PYP. For example, there is 
a new modular system in the English PYP courses at KFPUM, which places students in the appropriate level of English proficiency and supports a more homogenized section. Moreover, students' English proficiency improved with the modular system as most of them were able to score 500 in the TOEFL exam by the end of the session (Al-assaf, 2015). In addition, in an unpublished study on KSU students - (Center for Excellence in Learning and Teaching, 2013) ${ }^{1}$ - it was shown that the average GPA of students at the end of the first semester after completing the PYP was 3.61 / 5.00. This GPA was higher than the GPA of students who did not go through the PYP program (average GPA 2.61). Moreover, for those who completed the PYP, the withdraw percentages among males decreased from $26 \%$ to $22 \%$. This study also revealed that the correlation between PYP GPA and first year GPA (after completing the PYP) is higher than the correlation between HSGPA or GAT and first year GPA (after completing the PYP). One of the most outstanding outcomes of the study is that students' English proficiency has increased remarkably. Moreover, there is a positive correlation between students' performance in PYP mathematics courses and their performance in program-level mathematics courses. This study indicates that PYP is the right tool to prepare students for higher education and to measure their readiness. The findings similarly implied that PYP has a great influence on preparing students for the demand of college life. They are more independent, responsible, and accountable. Their skills in time management, communication, and research compensations have increased. Their confidence also improved, in addition to their academic skills, English proficiency, mathematical knowledge and health awareness. Overall, students are more ready with the PYP.

\section{STAGE II FINDINGS}

This study examined students' performance upon completion of PYP at a private university at KSA. Table 1 below shows the descriptive statistics. Students' average scores were $94.03 \%$ for high school and $79.25 \%$ for GAT. Average GPA upon completing PYP is 2.74 out of 4.00. Female GPA (2.94) is slightly higher than male GPA (2.54). Similarly, female students' perform is slightly better than male students in mathematics courses; the average GPA for female students is 3.0, whereas the average GPA for male students is 2.486 .

Table 1

Descriptive Stat. of all variables

\begin{tabular}{lllll}
\hline & High School & GAT & PYP GPA & Math GPA \\
\hline Mean & $94.03 \%$ & $79.25 \%$ & $2.74 / 4.00$ & $2.74 / 4.00$ \\
\hline Std. Deviation & 6.57 & 8.29 & 0.75 & 0.95 \\
\hline Minimum & $70 \%$ & $60 \%$ & $0.89 / 4.00$ & $1.00 / 4.00$ \\
\hline Maximum & $100 \%$ & $99 \%$ & $4.00 / 4.00$ & $4.00 / 4.00$ \\
\hline $\mathrm{N}$ & 1200 & 1200 & 1200 & 1200 \\
\hline
\end{tabular}

\footnotetext{
${ }^{1}$ The study was conducted in 2013 by the Center for Excellence in Learning and Teaching at King Saud University and was supervised by the Vice Rectorate of Educational and Academic Affairs: https://celt.ksu.edu.sa/sites/celt.ksu.edu.sa/files/attach/tqwym_lsn_lthdyry.pdf
} 
Students completed two consecutive basic algebra mathematical courses. Most students did well in the second mathematics course with about $80 \%$ passing percentage. However, students struggled in the first course and about $40 \%$ failed the course and repeated it.

\section{DISCUSSION}

Saudi students face a problem when they move to higher education specifically in their college-level mathematics classes. Their personal characteristic and study style are not compatible with higher education demand. This problem actually is a shared concern in many countries around the world including the U.S; Freshmen U.S. students are more comfortable with teacher-centered classrooms. Stadler, Bengmark, Thunberg, and Winberg (2013) reported that "beginners rely heavily on the teacher, while experienced students re-orient themselves from the teacher to other kinds of mathematical resources" (p. 2436). To address these issues, the education in the KSA has gone under tremendous improvement (Ministry of Education, 2015). Stakeholders have implemented several approaches - at the school level and at the university level - to reduce the challenges of transitions from secondary education to tertiary education: 1) presentations of the contents have changed in all mathematics and science textbooks to address the language barrier; 2) learning style in secondary schools, including the level of tasks given to students, is more demanding to help prepare independent graduates; 3) the assessment and evaluation process is now standardized and use multiple measurements to support the selection process to higher education institutions; 4) finally, a complete one-year program is introduced to help prepare students academically and professionally for college demand. Recent studies have suggested that high school graduates are now more ready than before for higher education.

By looking at a sample from a private university, the descriptive statistics indicates that students' performance is satisfactory. The distribution of grades in mathematics PYP course is normal. However, the passing percentage of the second mathematics course was noticeable to be greater that the first mathematics course. It is clear from examining the content of both courses that the second course is more mathematically demanding. This coincide with Dimitov and AlHarbi (2014) and suggests that the transition challenge affected students' performance; they performed better in a more demanding class once they got used to the environment and learning style.

\section{LIMITATION AND FUTURE RESEARCH}

This paper used only descriptive statistics to explain the characteristics of PYP students at one private university. This paper is not making any inferential statistics or claims any prediction about the population. The goal is rather to understand the current situation especially that the education system in Saudi Arabia has gone through several transformations in the past few decades including structure, procedures and content.

Research studies have suggested that high school graduates are probably more prepared now than before for higher education programs (Alshumaimeri, 2013) a claim that is supported by the descriptive statistics in Table 1. Nevertheless, enhancing high school graduates' readiness and adaptation to the new environment has been moving slowly. 
The PYP has been established more than a decade ago and the transformation in school curricula and pedagogy have been implemented for over six years; yet, the improvements of high schools' outcomes are hardly recognized. This suggests that there is still more work to be done. The cooperation from all stakeholders to address these challenges, to support curriculum reform, to enhance pre-college programs, and to better prepare high school graduates is urgently needed.

\section{REFERENCES}

AlHarbi, K. A. (2012). High school graduates' performance in aptitude and basic knowledge in the Kingdom of Saudi Arabia (Report No. TR005-2012). Riyadh, KSA: National Center for Assessment in Higher Education.

Al-Amri, M. (2011). Higher education in Saudi Arabia. Journal of Higher Education Theory and Practice, 11(4), 88-91.

Al-Assaf, A. (2015, April). The Prep year program and KFPUM. Paper presented at the First National Conference of Preparatory Year in Saudi Universities, Riyadh, KSA.

Alenaizy, B. (2015, April). The reality of the PYP from the perspectives of Saudi press. Paper presented at the First National Conference of Preparatory Year in Saudi Universities, Riyadh, KSA.

Alghamdi, M. (2015). Satisfaction of preparatory year students with university services. World Journal of Education, 5(5), 117-129.

Al-Jeraiwi, A. (2015, April). Preparatory year deanship experience at King Saud University in the field of e-learning. Paper presented at the First National Conference of Preparatory Year in Saudi Universities, Riyadh, KSA.

AlMoshari Alsaud, F. A. (2012). A vision in the reality of high school education and its developments (Report No. TR004-2012). Riyadh, KSA: National Center for Assessment in Higher Education.

Alnahdi G. H. (2015). Aptitude tests and successful college students: The predictive validity of the General Aptitude Test (GAT) in Saudi Arabia. International Educational Studies, 8(4), 1-6.

Alnatheer, M. A. (2009). AlSaudia fi thail algaema maa Qatar wa Ghana!! [Saudi Arabia at the end of the list with Qatar and Ghana!!] Majala Almarefh Magazine, 169. Retrieved from http://www.almarefh.org/news.php?action=show\&id=599.

Al-Owidha, A. (2013). The Saudi standardized achievement admission test (SAAT): A study of construct-related validity evidence (Report No. TR038-2013). Riyadh, KSA: National Center for Assessment in Higher Education.

AlQataee, A. (2012). Test length and precision: How precise the GAT will be if the test is shortened? (Report No. TR008-2012). Riyadh, KSA: National Center for Assessment in Higher Education. 
AlQataee, A. A., \& AlHarbi, K. A. (2012). The university admission criteria ability to predict the cumulative average for the first year (Report No. TR009-2012). Riyadh, KSA: National Center for Assessment in Higher Education.

Alsaeed, M. (2012). Teacher Knowledge That Supports Student Processes in Learning Mathematics: A Study at All-Female Middle Schools in Saudi Arabia (Doctoral Dissertation). Retrieved from OhioLink. (ohiou1336411716)

Al-Seghayer, K. (2014). The actuality, inefficiency, and needs of EFL teacherpreparation programs in Saudi Arabia. International Journal of Applied Linguistics \& English Literature, 3(1), 143-151.

Alshehri, M. A., \& Ali. H. S. (2016). The compatibility of developed mathematics textbooks' content in Saudi Arabia (Grades 6-8) with NCTM standards. Journal of Education and Practice, 7(2), 137-142.

Alshumaimeri, Y. A. (2013). The effect of an intensive English language program on first year university students' motivation. Journal of Educational \& Psychological Sciences, 14(1), 11-32.

Alshumaimeri, Y., \& Alghamdi, F. (2009, March). Perceptions of Saudi PYP students about the IEP at King Saud University. Paper presented at IATEFL 43rd Annual Conference, Cardiff, UK.

Bergsten, C., Jablonka, E., \& Ashjari, H. (2016, July). The transition from secondary to tertiary mathematics education-a Swedish study. Paper presented at the 13th International Congress on Mathematical Education, Hamburg, Germany.

Center for Excellence in Learning and Teaching (2013). Evaluation PYP at King Saud University. Unpublished study, Center for Excellence in Learning and Teaching, King Saud University, Riyadh, KSA. Retrieved from https://celt.ksu.edu.sa/sites/celt.ksu.edu.sa/files/attach/tqwym_lsn_lthdyry.pdf

Dimitov, D., \& AlHarbi, K. A. (2014). Examining students' performance on pre-college tests (GAT and SAAT), college GPA, and post-college tests (PGAT and Teacher Test): The case of science colleges at Saudi universities (Report No. TR073-2014). Riyadh, KSA: National Center for Assessment in Higher Education.

Excellence Research Center of Science and Mathematics Education. (2011). Obeikan chair for Science and Mathematics Education organized seminar on "science and mathematics curricula upgrading project: Theory and practice”. Riyadh, KSA: Excellence Research Center of Science and Mathematics Education. Retrieved from http://ecsme.net/en/index.cfm?method=home.con\&ContentID $=347$

Hastings, C. J. (2012). Attitudes and Acculturation: A Qualitative Case Study of EFL Teachers in Saudi Arabia (Doctoral Dissertation). Retrieved from Dissertation Abstract International. (DAI-A 73/12(E), 1034253505).

Khashoggi, J. (2014, February 8). Saudi Arabia's education system in the spotlight again. AlHayat Newspaper. Retrieved from http://www/alhayat.com/opinionsderails/600968 
Khoshaim, H. B., \& Ali, T. (2015). Indicators of students' success at higher education institutions. In F. Uslu (Ed.), Proceedings of the International Conference on Education and Social Sciences (pp. 521-529). Istanbul, Turkey: International Organization Center of Academic Research.

Khoshaim, H. B. \& Ali, T. (2015-b). Students' Struggle with First-Year University Mathematics Courses in Saudi Arabia. College Student Journal, 49(4), 588-598.

Lobo, A. (2012). Will we meet again? Examining the reasons why students are leaving first year university courses and moving towards an approach to stop them. The International Journal of Learning, 18, 199-212.

McMullen, M. G. (2014). The value and attributes of an effective preparatory English program: Perceptions of Saudi University students. The English Language Teaching, 7(7), 131-140.

Ministry of Education. (2015). Education in the Kingdom of Saudi Arabia: National indicator and international benchmarking. Riyadh, KSA: Observatory on Education.

Ministry of Education. (n.d.). Retrieved from: http://www.moe.gov.sa/ar/Pages/default.aspx.

National Center for Assessment in Higher Education (NCAHE). (n.d.). Retrieved from http://www.qiyas.sa/Sites/English/Tests/Pages/GiftednessAndCreativity.aspx

Oxford Business Group. (2012). The report: Saudi Arabia 2012. London, UK: Author.

Patterson, B. F., Mattern, K. D., \& Swerdzewski, P. (2012). Are the best scores the best scores for predicting college success? Journal of College Admission, 21(7), 35-45.

Radcliffe, R. A., \& Bos, B. (2013). Strategies to prepare middle school and high school students for college and career readiness. The Clearing House: A Journal of Educational Strategies, 86(4), 136-141. doi: 10.1080/00098655.2013.782850

Rahman, M. M., \& Alhaisoni, E. (2013). Teaching English in Saudi Arabia: Prospects and challenges. Academic Research International, 14(1), 112-118.

Stadler, E., Bengmark, S., Thunberg, H., \& Winberg, M. (2013). Approaches to learning mathematics-differences between beginning and experienced university students. In B. Ubuz, C. Haser, \& M. Mariotti (Eds.), Proceedings of the Congress of the European Society for Research in Mathematics Education, 8, 2436-2445. Ankara, Turkey: Middle East Technical University.

University of Dammam. (n.d.). Retrieved from http://www.uod.edu.sa/en/events/thefirst-national-conference-for-the-preparatory-year-in-saudi-universities.

Uyar, A., \& Güngörmüş, A. H. (2011). Factors associated with student performance in financial accounting course. European Journal of Economic and Political Studies, 4(2), 139-154.

Zwick, R., \& Sklar, J. C. (2005). Predicting college grades and degree completion using high school grades and SAT scores: The role of student ethnicity and first language. 
American Educational Research Journal, 42(3), 439-464. doi: $10.3102 / 00028312042003439$.

\section{Turkish Abstract}

Suudi Arabistan'daki Lise Mezunlarının Yükseköğretime Hazırlık Durumu

Suudi Arabistan'daki eğitim sisteminde niceliksel ve niteliksel olarak büyük bir iyileşme olmuştur. Bununla birlikte, birçok araştırmacı lise mezunlarının yüksek öğretime hazır olmadığını belirtmişlerdir. Özellikle akademik programlar için matematiksel yeterlilikler ve ileri yeterlilik becerileri göz önüne alındığında, Suudi öğrencilerin eksiklerinin olduğu bulunmuştur. $\mathrm{Bu}$ ögrencilerin birçoğu, yükseköğretime başladığında ilk yıldan itibaren başarısız olur ve eğitimini bırakır. $\mathrm{Bu}$ bağlamda ortaöğretimden yüksek öğretime geçişteki zorlukları ele alan çeşitli yaklaşımlar geliştirilmiştir. Bu girişimlerden bazıları okul müfredatını ele almış; diğerleri ise üniversitelerindeki ilk yıllarında öğrencilerin yeterliliklerini artırmaya odaklanmışlardır.

Anahtar Kelimeler: yüksek öğretim, matematik yeterlilikleri, hazırlık yılı programı, yükseköğretime geçiş

\section{French Abstract}

L'empressement de Diplômés de Lycée pour Enseignement supérieur dans l'Arabie Saoudite

Il y a eu une amélioration énorme du système éducatif dans l'Arabie Saoudite quantitativement et qualitativement. Néanmoins, beaucoup de chercheurs ont indiqué que les diplômés de lycée ne sont pas prêts pour l'enseignement supérieur. Particulièrement en considérant des compensations mathématiques, des compétences haut exigées pour des programmes universitaires tertiaires, des étudiants saoudiens ont été trouvés déficients. Beaucoup eux et par conséquent laisser tomber, quitté - de la toute première année. Il y a eu plusieurs approches qui ont relevé le défi de transition de l'enseignement secondaire à l'enseignement supérieur. Certaines de ces tentatives ont adressé des programmes d'études scolaires. D'autres concentrés sur les compensations d'étudiants d'amélioration pendant leur première année à université.

Mots Clés: enseignement supérieur, compétences mathématiques, programme d'année préparatoire, transition à enseignement supérieur

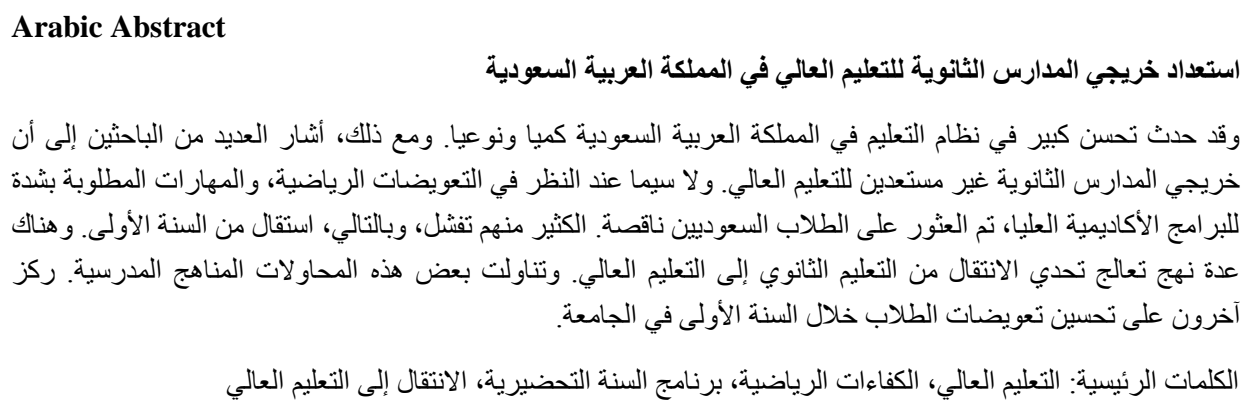




\section{German Abstract \\ Bereitschaft zur Tertiärbildung von High-school-absolventen in Saudi Arabien}

Es gab eine enorme Verbesserung des Bildungssystems in Saudi-Arabien quantitativ und qualitativ. Trotzdem haben viele Forscher darauf hingewiesen, dass High-School-Absolventen nicht bereit für die Hochschulbildung sind. Vor allem bei der Betrachtung mathematischer Kompensationen, hochgeforderter Fähigkeiten für tertiäre akademische Programme, wurden saudische Studenten mangelhaft gefunden. Viele von ihnen scheitern - und damit beenden - vom ersten Jahr an. Es gab mehrere Ansätze, die sich der Herausforderung des Übergangs von der Sekundarstufe bis zur Hochschulbildung näherten. Einige dieser Versuche richteten sich an Schulcurricula. Andere konzentrierten sich auf die Verbesserung der Entschädigung der Studenten während ihres ersten Jahres an der Universität.

Schlüsselwörter: hochschulbildung, mathematische kompetenzen, vorbereitungsjahresprogramm, übergang zum tertiärbereich

\section{Malaysian Abstract \\ Kesediaan Graduan Sekolah Tinggi untuk Pendidikan Tertiari di Arab Saudi}

Terdapat peningkatan yang besar dalam sistem pendidikan di Arab Saudi secara kuantitatif dan kualitatif. Walau bagaimanapun, ramai penyelidik menunjukkan bahawa graduan sekolah tinggi tidak bersedia untuk pendidikan tinggi. Terutamanya apabila mempertimbangkan kecekapan matematik, kemahiran tinggi menuntut program akademik pengajian tinggi, pelajar Arab telah didapati kekurangan. Banyak daripada mereka gagal dan dengan itu, berhenti dari tahun pertama. Terdapat beberapa pendekatan yang merujuk kepada cabaran peralihan daripada pendidikan menengah untuk pendidikan tinggi. Beberapa percubaan ini ditangani melalui kurikulum sekolah. Selain itu memberi tumpuan kepada meningkatkan pampasan pelajar pada tahun pertama mereka di universiti.

Kata Kunci: pendidikan tinggi, kecekapan matematik, program tahun persediaan, peralihan kepada pendidikan tinggi

\section{Russian Abstract \\ Выпускники Высших Учебных Заведений Готовятся к Университетскому Образованию в Саудовской Аравии}

Произошло значительное улучшение системы образования в Саудовской Аравии в количественном и качественном виде. Тем не менее, многие исследователи указали, что выпускники средней школы не готовы к получению высшего образования. Особенно, когда рассматривают математические компенсации, высокопрофессиональные навыки для высших академических программ, саудовские студенты были признаны несовершенными. Многие терпят неудачу, и, следовательно, исключаются с первого года. Существует несколько подходов к решению проблемы перехода от среднего образования к высшему образованию. Некоторые из этих попыток касались школьных программ. Другие сосредоточились на повышении компенсаций студентов в течение их первого года в университете.

Ключевые Слова: высшее образование, математическая компетентность, подготовительная годовая программа, переход к третичному образованию 